\title{
Note
}

\section{Deep diving behavior observed in yellowfin tuna (Thunnus albacares)}

\author{
Laurent Dagorn ${ }^{1, a}$, Kim N. Holland ${ }^{2}$, Jean-Pierre Hallier ${ }^{3}$, Marc Taquet ${ }^{4}$, Gala Moreno ${ }^{5}$, Gorka Sancho ${ }^{6}$, \\ David G. Itano ${ }^{7}$, Riaz Aumeeruddy ${ }^{8}$, Charlotte Girard ${ }^{1}$, Julien Million ${ }^{9}$ and Alain Fonteneau ${ }^{10}$ \\ IRD, PO Box 570, Victoria, Seychelles \\ 2 Hawaiian Institute of Marine Biology, University of Hawaii, PO Box 1346, Kaneohe, Hawaii 96744, USA \\ 3 Regional Tuna Tagging Project - Indian Ocean (RTTP-IO), c/o IOTC PO Box 1011, Victoria, Seychelles \\ ${ }^{4}$ IFREMER, BP 60, rue Jean Bertho, 97822 Le Port Cedex, La Réunion, France \\ 5 AZTI - Tecnalia / Unidad de Investigación Marina, Txatxarramendi Ugartea z/g, 48395 Sukarrieta, Spain \\ ${ }^{6}$ Grice Marine Laboratory, College of Charleston, 205 Fort Johnson, Charleston, SC 29412, USA \\ 7 University of Hawaii, Pelagic Fisheries Research Program, 1000 Pope Road, MSB 312, Honolulu, Hawaii 96822, USA \\ 8 Seychelles Fishing Authority, PO Box 449, Victoria, Seychelles \\ 9 IOTC, PO Box 1011, Victoria, Seychelles \\ ${ }^{10}$ IRD, CRHMT, Av. J. Monnet, BP 171, 34203 Sète Cedex, France
}

Received 8 February 2006; Accepted 27 February 2006

\begin{abstract}
Yellowfin tuna (Thunnus albacares) are known to preferentially occupy the surface mixed layer above the thermocline and it has been suggested that they are physiologically restricted to water temperatures no more than $8{ }^{\circ} \mathrm{C}$ colder than surface waters. However, we here report for dive data acquired from a large yellowfin tuna which demonstrate for the first time that this species is indeed capable of making prolonged dives into deep cold waters. A yellowfin tuna (134 cm fork length) caught near an anchored fish aggregating device (FAD) in the Seychelles (Western Indian Ocean) was equipped with an internally implanted archival tag and released. The fish was recaptured 98 days later. As predicted for this species, this fish spent $85 \%$ of its time shallower than $75 \mathrm{~m}$ (maximum thermocline depth experienced by the fish) but, over the course of the track, it performed three deep dives to $578 \mathrm{~m}, 982 \mathrm{~m}$ and $1160 \mathrm{~m}$. Minimum ambient water temperatures recorded at these depths were $8.6{ }^{\circ} \mathrm{C}, 7.4{ }^{\circ} \mathrm{C}$ and $5.8{ }^{\circ} \mathrm{C}$ respectively and varied by up to $23.3{ }^{\circ} \mathrm{C}$ from surface temperatures. The fish spent $8.3 \%$ of its time in waters more than $8{ }^{\circ} \mathrm{C}$ colder than the surface layer and daily experienced a wide range of sea temperatures (mode at $15-16^{\circ} \mathrm{C}$ ) and of temperatures of the gut cavity (mode at $6{ }^{\circ} \mathrm{C}$ ). The reason for these dives can not be known. These depths and temperatures significantly exceed those reported in the literature so far and clearly demonstrate that this species has the physiological and behavioral ability to penetrate deep cold sections of the ocean.
\end{abstract}

Key words: Archival tag / Vertical movements / Diving behavior / Swimming speed / Yellowfin tuna / Indian Ocean

\section{Introduction}

Ultrasonic telemetry has been used to obtain extensive and detailed data on the horizontal and vertical movements of tropical tuna (Holland et al. 1990; Cayré 1991; Holland et al. 1992; Block et al. 1997; Marsac and Cayré 1998; Brill et al. 1999; Dagorn et al. 2000). These studies produced precise information on habitat selection and the physiological abilities and tolerances of tuna. This knowledge is of critical importance for the development of effective fishery management schemes (Brill 1994). Yellowfin tuna (Thunnus albacares) generally spend most of their time either in the mixed layer or at the

\footnotetext{
a Corresponding author: dagorn@ird.fr
}

top of the thermocline (Holland et al. 1990; Brill et al. 1999). To date, no dive deeper than $500 \mathrm{~m}$ (464 m in Carey and Olson 1982) was reported for a yellowfin tuna and the coldest absolute temperature recorded for a sonically tracked yellowfin tuna was $7{ }^{\circ} \mathrm{C}$ (Block et al. 1997) for a single dive of one minute to almost $300 \mathrm{~m}$. By comparing ultrasonic telemetry data obtained from large yellowfin tuna in Hawaiian waters and in the eastern Pacific, Brill et al. (1999) found that the lower temperature limit of this species was set by water $8{ }^{\circ} \mathrm{C}$ colder than the mixed layer and they suggested that yellowfin are stenothermal and their temperature tolerance (and, therefore, depth) is determined by temperature differences relative to the surface temperature rather than by absolute water 
temperature per se. As indicated by Brill (1994), there have been no laboratory studies on the cold temperature tolerance of tropical tuna since the original work of Dizon et al. (1977).

Recent advances in the capabilities of archival tags now allow collection of long term data regarding the vertical behavior of tuna species (Schaefer and Fuller 2002, 2005). However, to date, no data from yellowfin tuna equipped with archival tags have been published that indicate any behavior other than those previously observed by active acoustic telemetry. In this note, we wish to report on the swimming depths and temperatures of a single large yellowfin tuna that indicate that this species has much greater vertical range and broader physiological capability than previously reported.

\section{Materials and methods}

A yellowfin tuna (134 cm FL, approximately $45-50 \mathrm{~kg}$ ) was captured by a research vessel ${ }^{1}$ using a surface trolling lure near a fish aggregating device (FAD) anchored in water $600 \mathrm{~m}$ deep off $\mathrm{D}^{\prime}$ Arros island $\left(5^{\circ} 23 \mathrm{~S}\right.$ and $\left.53^{\circ} 20 \mathrm{E}\right)$ in the Amirantes archipelago (Seychelles, Indian Ocean). An archival tag (Wildlife Computers, MK9) was inserted in the peritoneal cavity using standard implantation techniques (e.g., Schaefer and Fuller 2002), with the stalk outside the fish (Fig. 1). The fish was measured to the nearest $\mathrm{cm}$ and marked with an external Hallprint $14 \mathrm{~cm}$ plastic dart tag and released within $300 \mathrm{~m}$ of the FAD of capture on the 14th of October 2004. The archival tag was set to record depth, sea temperature, body temperature (body cavity) and light level every $30 \mathrm{~s}$. The original calibration of the tag indicated that at $1000 \mathrm{~m}$, it recorded $1005 \mathrm{~m}$, and at $1500 \mathrm{~m}$, it recorded $1534 \mathrm{~m}$. Thus, we can be fairly certain that dives between 1000 and $1500 \mathrm{~m}$ are accurate within $35 \mathrm{~m}$.

Plotting sea temperature versus depth during the dives allows to estimate the depth of the thermocline.

\section{Results}

The fish was recaptured the 20th of January 2005 by a tuna purse seiner approximately 250 nautical miles west of the release position $\left(5^{\circ} 45 \mathrm{~S}\right.$ and $\left.49^{\circ} 24 \mathrm{E}\right)$, after 98 days at liberty. However, the tag was only returned to researchers in January 2006. The fish spent $85 \%$ of its time between the surface and the depth of $75 \mathrm{~m}$, which was the maximum depth of the thermocline experienced by the fish during its 98-day journey. However, on three separate days within a period of one month, it exhibited three deep dives (Fig. 2) reaching the depths of $578 \mathrm{~m}$ (24 Oct. 2004 at 17:50 local time), $982 \mathrm{~m}$ (24 Nov. 2004 at 19:40 local time) and $1160 \mathrm{~m}$ (12 Dec. 2004 at 00:05 local time).

Two of the dives began and ended very close to the surface whereas on one dive (the first, Fig. 2a), the fish spent approximately 20 min just below the mixed layer before descending at a mean vertical speed of $1.18 \mathrm{~m} \mathrm{~s}^{-1}$ ( 0.88 body length per second $\left.-\mathrm{BL} \mathrm{s}^{-1}\right)$ to $537 \mathrm{~m}\left(9.2^{\circ} \mathrm{C}\right)$ and, after slowing its descent,

1 Indian Ocean Explorer, chartered by the EU FADIO project (Fish Aggregating Devices as Instrumented Observatories of pelagic ecosystems, www. fadio.ird.fr).

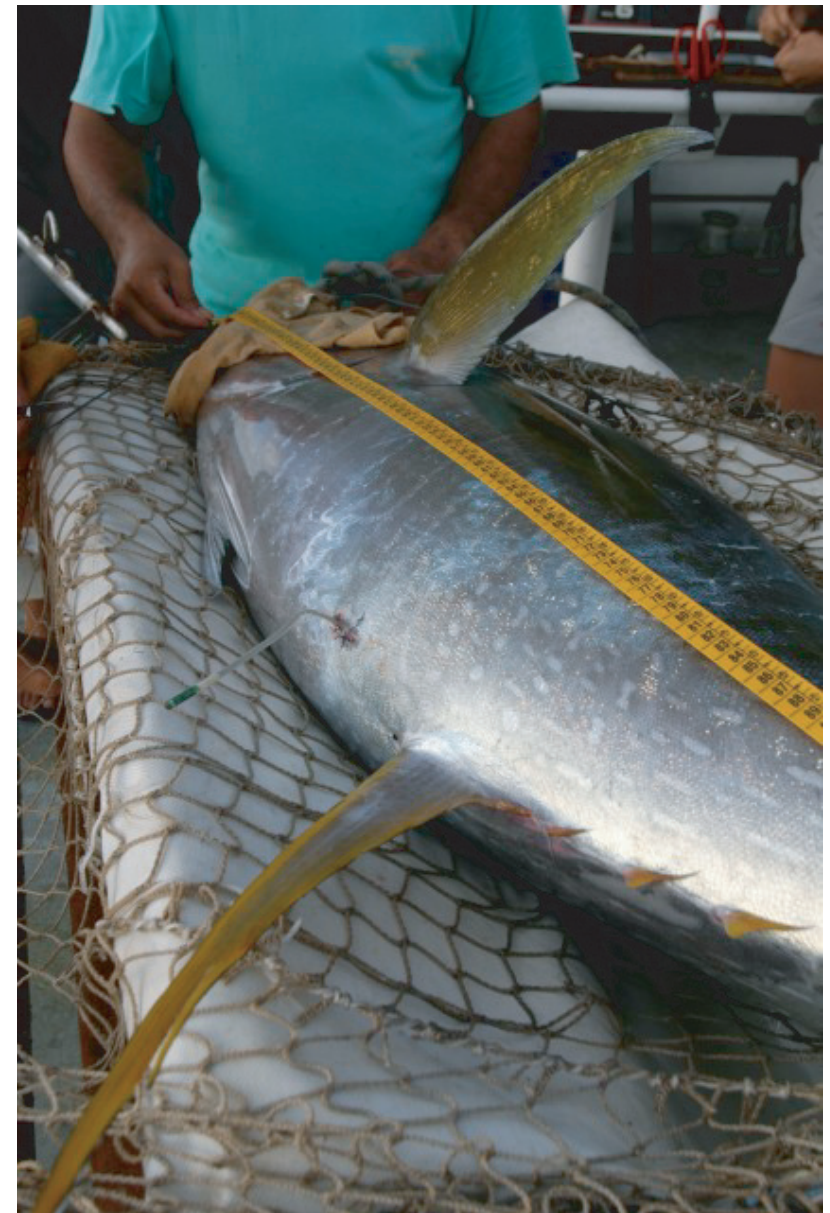

Fig. 1. Picture of the 134-cm yellowfin tuna equipped with the archival tag (Wildlife Computers MK9) before release.

reached a maximum depth of $578 \mathrm{~m}\left(8.6{ }^{\circ} \mathrm{C}\right)$. The fish then immediately swam up in a quasi-regular ascent at $0.46 \mathrm{~m} \mathrm{~s}^{-1}$ $\left(0.35 \mathrm{BL} \mathrm{s}^{-1}\right)$. During this dive, the fish spent $10 \mathrm{~min}$ in waters colder than $10{ }^{\circ} \mathrm{C}$ and a total of 49 min below the thermocline (40 m).

The second deep dive (Fig. 2b) started from $7 \mathrm{~m}\left(30.0^{\circ} \mathrm{C}\right)$ below the surface and the fish descended to $737 \mathrm{~m}\left(8.8^{\circ} \mathrm{C}\right)$ at a constant vertical speed of $1.43 \mathrm{~m} \mathrm{~s}^{-1}\left(1.07 \mathrm{BL} \mathrm{s}^{-1}\right)$ and finally reached a maximum depth of $982 \mathrm{~m}\left(7.4{ }^{\circ} \mathrm{C}\right)$ Then, the fish started to swim up following a "sawtooth" pattern during $36 \mathrm{~min}$ at a mean vertical speed of $0.16 \mathrm{~m} \mathrm{~s}^{-1}\left(0.12 \mathrm{BL} \mathrm{s}^{-1}\right)$. The second part of the ascent was faster and more regular $\left(1.07 \mathrm{~m} \mathrm{~s}^{-1}\right.$, i.e. $\left.0.80 \mathrm{BL} \mathrm{s}^{-1}\right)$. In total, during this dive, the fish spent $1 \mathrm{~h} 35$ in waters colder than $10{ }^{\circ} \mathrm{C}$ and a total of $1 \mathrm{~h} 46$ below the thermocline $(60 \mathrm{~m})$.

The deepest dive $(1160 \mathrm{~m}$, Fig. 2c) started slowly from $9 \mathrm{~m}$ $\left(29.1^{\circ} \mathrm{C}\right)$ to $80 \mathrm{~m}\left(20.7{ }^{\circ} \mathrm{C}\right)$. Then, the fish made a quick descent to the depth of $960 \mathrm{~m}\left(7.2^{\circ} \mathrm{C}\right)$ at an average vertical speed of $1.33 \mathrm{~m} \mathrm{~s}^{-1}\left(1.00 \mathrm{BL} \mathrm{s}^{-1}\right)$, with a maximum instantaneous speed of $4.88 \mathrm{~m} \mathrm{~s}^{-1}\left(3.64 \mathrm{BL} \mathrm{s}^{-1}\right)$. The second part of the descent was slower $\left(0.13 \mathrm{~m} \mathrm{~s}^{-1}, 0.10 \mathrm{BL} \mathrm{s}^{-1}\right)$ reaching the maximum depth of $1160 \mathrm{~m}\left(5.8{ }^{\circ} \mathrm{C}\right)$. The fish started to swim up exhibiting "sawtooth" oscillations for $47.5 \mathrm{~min}$ (from 1160 to $871 \mathrm{~m})$ at an average vertical speed of $0.10 \mathrm{~m} \mathrm{~s}^{-1}$ 
a)

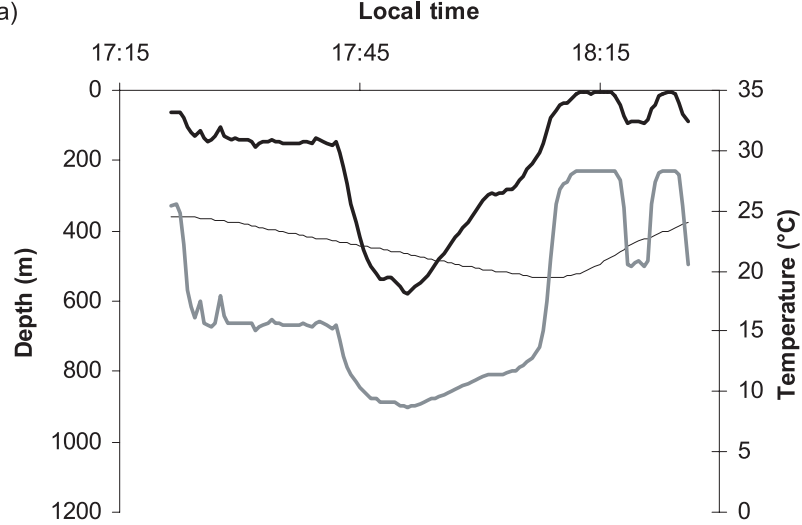

b)

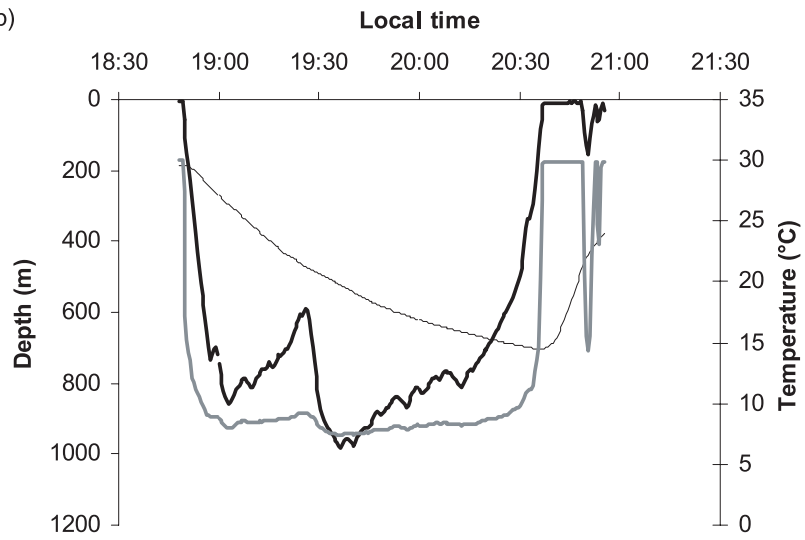

c)

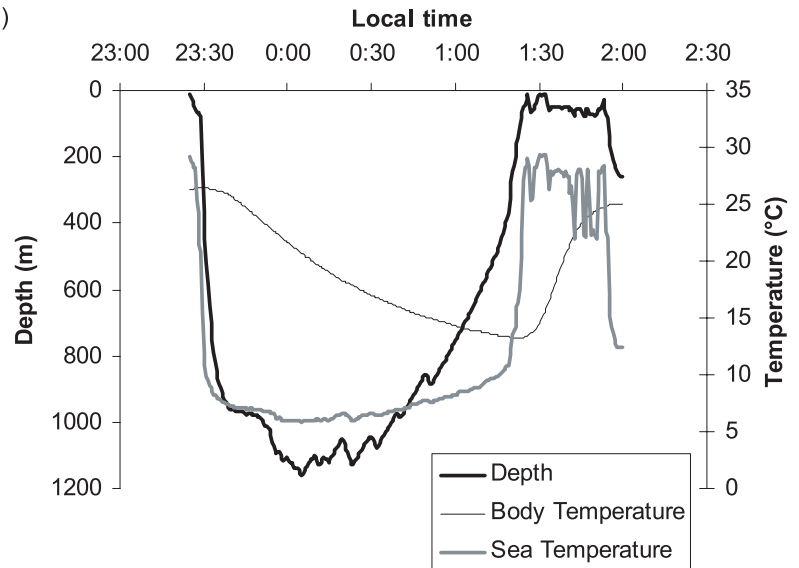

Fig. 2. Swimming depths (m), body (gut cavity) and sea temperatures $\left({ }^{\circ} \mathrm{C}\right)$ during the three deep dives; a) $\max .578 \mathrm{~m}$; b) max. $982 \mathrm{~m}$; c) $\max .1160 \mathrm{~m}$.

$\left(0.07 \mathrm{BL} \mathrm{s}^{-1}\right)$, then swam up faster to $464 \mathrm{~m}\left(9.8^{\circ} \mathrm{C}\right)$ at $0.29 \mathrm{~m} \mathrm{~s}^{-1}\left(0.22 \mathrm{BL} \mathrm{s}^{-1}\right)$. The last part of the ascent was performed at $0.54 \mathrm{~m} \mathrm{~s}^{-1}\left(0.40 \mathrm{BL} \mathrm{s}^{-1}\right)$. In total, the fish spent $1 \mathrm{~h} 46$ in waters colder than $10^{\circ} \mathrm{C}$ and a total of $1 \mathrm{~h} 57$ below the thermocline $(60 \mathrm{~m})$.

The difference of sea temperature experienced by the fish during these three dives ranged from 16.9 to $23.3{ }^{\circ} \mathrm{C}$ (Table 1 ). On all three dives, the rate of body warming was faster than the rate of cooling. This rate difference indicates that the animal was actively thermoregulating sensu Holland et al. (1992). The increase in body temperature began when the fish reached
Table 1. Sea and body (gut cavity) temperatures experienced by the yellowfin tuna during the three deep dives.

\begin{tabular}{lccc}
\hline & $578-\mathrm{m}$ dive & 982-m dive & $1160-\mathrm{m}$ dive \\
\hline $\begin{array}{l}\text { Range of water } \\
\text { temperature }\left({ }^{\circ} \mathrm{C}\right) \text { and } \\
\text { change in temperature } \\
\text { during dive }\end{array}$ & $25.5-8.6(16.9)$ & $30.0-7.4(22.6)$ & $29.1-5.8(23.3)$ \\
\hline $\begin{array}{l}\text { Range of body } \\
\text { temperature }\left({ }^{\circ} \mathrm{C}\right) \text { and } \\
\text { change in temperature } \\
\text { during dive }\end{array}$ & $24.4-19.4(5.0)$ & $29.6-14.4(15.2)$ & $26.3-13.2(13.1)$ \\
\hline
\end{tabular}

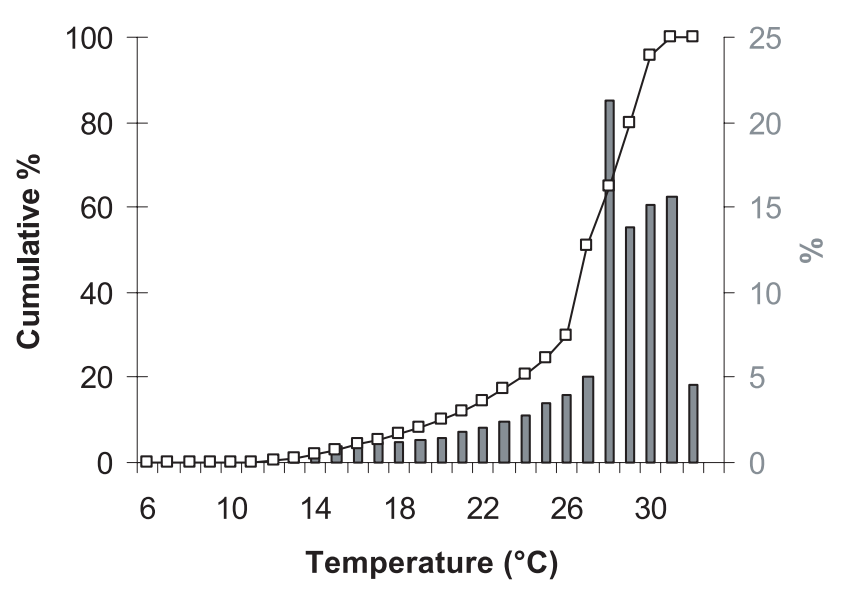

Fig. 3. Time-at-temperature of the yellowfin tuna during its 98-day journey. The line shows the cumulative percentage.

waters that are at the same temperature as the body (Fig. 2). The first dive $(578 \mathrm{~m})$ only induced a $5{ }^{\circ} \mathrm{C}$ decrease in the body temperature, while the other dives (982 and $1160 \mathrm{~m}$ ) led to $15.2{ }^{\circ} \mathrm{C}$ and $13.1{ }^{\circ} \mathrm{C}$ decreases in body temperature, respectively (Table 1 ). The lowest absolute body temperature recorded was $13.2{ }^{\circ} \mathrm{C}$ during the deepest dive but after the fish had begun its ascent and was at $110 \mathrm{~m}$ when its body temperature matched the sea temperature. This point was reached $78 \mathrm{~min}$ after it reached the maximum depth $(1160 \mathrm{~m})$.

Figure 3 shows the time-at-temperature distribution where temperature bins are expressed as degree intervals. We estimated the maximum water temperature experienced by the fish on each day of the track. Over the 98 days, these maximum values (sea surface temperatures) ranged from 28.0 to $32.2{ }^{\circ} \mathrm{C}$. The fish spent $8.3 \%$ of its time at temperatures below $20^{\circ} \mathrm{C}$ (which, by extension, are also more than $8{ }^{\circ} \mathrm{C}$ colder than the surface layer). The water temperatures experienced by the fish during its 98 -day journey ranged from $5.8{ }^{\circ} \mathrm{C}$ to $32.2^{\circ} \mathrm{C}$. The daily differences in water temperatures ranged from $9.7^{\circ} \mathrm{C}$ to $24.2^{\circ} \mathrm{C}$ with a mode at $15-16^{\circ} \mathrm{C}$, while the daily differences in body temperature (gut cavity) ranged from $1.1^{\circ} \mathrm{C}$ to $15.4{ }^{\circ} \mathrm{C}$, with a mode at $6{ }^{\circ} \mathrm{C}$ (Fig. 4).

\section{Discussion and conclusion}

Most of the time, this 134-cm yellowfin tuna swam at depths shallower than $75 \mathrm{~m}$ deep (which was the deepest thermocline experienced by the fish), which agrees with what was previously known on the vertical distribution of this species 


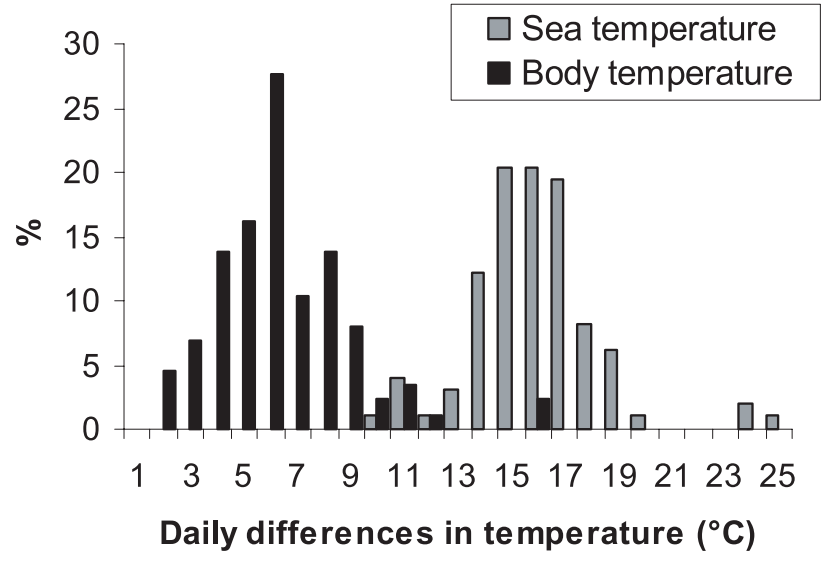

Fig. 4. Distribution of the daily differences in water (grey bars) and gut cavity (black bars) temperatures $\left({ }^{\circ} \mathrm{C}\right)$ experienced by the yellowfin tuna during its 98 -day journey.

(Holland et al. 1990; Brill 1994; Block et al. 1997). These distributional data are clearly important for fisheries management in terms of predicting the vulnerability of this species to various fishing gears. Nevertheless, the results from this track shed new light on the depth and temperature range of this species and on its physiological capabilities. Based on acoustic tracks from several studies, Brill et al. (1999) stated that the limit on the vertical range of yellowfin tuna appears to be the difference in temperature between the surface layer and waters below the thermocline rather than a specific absolute water temperature. Maximum swimming depths appeared to be limited by water temperatures $8{ }^{\circ} \mathrm{C}$ colder than the surface-layer water temperature. The behavior reported here demonstrates that this is obviously not the case. On the three deep dives the difference in temperatures was well above this threshold of $8{ }^{\circ} \mathrm{C}$ (in fact, up to $23.3{ }^{\circ} \mathrm{C}$ ). For more than $8.3 \%$ of its time, this fish was in water more than $8{ }^{\circ} \mathrm{C}$ colder than the surface layer and daily experienced large changes in ambient water temperature (mode at $415-16{ }^{\circ} \mathrm{C}$ ).

Of particular importance are the durations of the dives. That is, the time spent in water colder than the mixed layer and upper levels of the thermocline. Time below the thermocline was $49 \mathrm{~min}, 1 \mathrm{~h} 46$ and $1 \mathrm{~h} 57$ for dives 1,2 and 3 respectively. These prolonged excursions indicate that these were not "bounce dives" and that the animal had the ability to thermoregulate for extended periods of time and to also tolerate low oxygen levels for similarly impressive periods of time. Unfortunately, accurate oxygen levels were not recorded during the dives.

It is not possible to know why these deep dives occurred - they could be for foraging purposes, predator avoidance or anti-parasite behavior. Although the rarity of these deep dives suggests that this is not typical foraging behavior, the quite slow rate of descent and the prolonged time at depth does not suggest predator avoidance. Such behavior is probably signified by "bounce dives" at higher speeds such as over 6 body lengths per second (Holland et al. 1990). Tuna could dive to such deep and cold waters to get rid off parasites but almost no information currently exist on the effects of parasites on the behavior of tuna. When "ecological tags" are developed to collect information on the biological environment surrounding the tagged fish, it will be possible to better identify the reasons for such surprising deep dives by a yellowfin tuna.

Acknowledgements. This study was possible thanks to the collaboration of three projects funded by the European Union: FADIO (Fish Aggregating Devices as Instrumented Observatories of pelagic ecosystems), funded by the DG Research (QLRI-CT-2002-02773), the Regional Tuna Tagging Project - Indian Ocean, funded by the DG Development (REG/5504/003 EDF IX) and by DG-Fish through the extended programme for the collection of data and management of fisheries (defined by the Council Regulation (EEC) No. 1543/200). Three associations of tuna purse seiners from Spain and France also contributed to this study: OPAGAC, ANABAC, ORTHONGEL. We also want to thank the crew of the 'Indian Ocean Explorer' and the staff of the Wanainchi Marine Products Ltd (tuna cannery) for the tag recovery in Kenya.

\section{References}

Block B.A., Keen J.E., Castillo B., Brill R., Dewar H., Freund E., Marcinek D., Farwell C., 1997, Environmental preferences of yellowfin tuna (Thunnus albacares) at the northern extent of its range. Mar. Biol. 130, 119-132.

Brill R.W., 1994, A review of temperature and oxygen tolerance studies of tunas pertinent to fisheries oceanography, movement models and stock assessments. Fish. Oceanogr. 3, 204-216.

Brill R.W., Block B.A., Boggs C.H., Bigelow K.A., Freund E.V., Marcinek D.J., 1999, Horizontal movements and depth distribution of large adult yellowfin tuna (Thunnus albacares) near the Hawaiian Islands, recorded using ultrasonic telemetry: implications for the physiological ecology of pelagic fishes. Mar. Biol. 133, 395-408.

Carey F.G., Olson, R.J., 1982, Sonic tracking experiments with tunas. Collect. Vol. Sci. Pap. ICCAT 17, 458-466.

Cayré P., 1991, Behaviour of yellowfin tuna (Thunnus albacares) and skipjack tuna (Katsuwonus pelamis) around fish aggregating devices (FADs) in the Comoros Islands as determined by ultrasonic tagging. Aquat. Living Resour. 4, 1-12.

Dagorn L., Bach P., Josse E., 2000, Movement patterns of large bigeye tuna (Thunnus obesus) in the open ocean determined using ultrasonic telemetry. Mar. Biol. 136, 361-371.

Dizon A.E., Neil W.H., Magnuson J.J., 1977, Rapid temperature compensation of volitional swimming speeds and lethal temperatures in tropical tunas (Scombridae). Environ. Biol. Fishes 2, 83-92.

Holland K.N., Brill R.W., Chang R.K., 1990, Horizontal and vertical movements of yellowfin and bigeye tuna associated with fish aggregating devices. Fish. Bull. 88, 493-507.

Holland K.N., Brill R.W., Chang R.K., Sibert J.R., Fournier D.A., 1992, Physiological and behavioral thermoregulation in bigeye tuna (Thunnus obesus). Nature 358, 410-412.

Marsac F., Cayré P., 1998, Telemetry applied to behavior of yellowfin tuna (Thunnus albacares) movements in a network of fish aggregating devices. Hydrobiologia 371/372, 155-171.

Schaefer K.M., Fuller D.W., 2002, Movements, behavior, and habitat selection of bigeye tuna (Thunnus obesus) in the eastern equatorial Pacific, ascertained through archival tags. Fish. Bull. 100, 765-788.

Schaefer K.M., Fuller D.W., 2005, Behavior of bigeye (Thunnus obesus) and skipjack (Katsuwonus pelamis) tunas within aggregations associated with floating objects in the equatorial eastern Pacific. Mar. Biol. 146, 781-792. 